\title{
African Americans and Reconceptualization of Identity: Black Participation in World War I and the Rise of the New Negro Consciousness
}

\author{
Farshid Nowrouzi Roshnavand
}

University of Tehran, Iran

\section{Rajabali Askarzadeh Torghabeh}

Ferdowsi University of Mashhad, Iran

\section{Introduction}

After the first encounter between Western colonizers and the negroid in the fifteenth century, the Western consciousness embarked on a subtle mechanism which ultimately aimed to justify the heinous crimes and misdeeds committed against non-white, non-Christian subjects in the occupied lands. This mechanism provided a constructed image of the non-white subject in which certain characteristics were deliberately underscored; by exaggerating the differences of the non-white populations, the Western enterprise of colonization managed to Otherize and inferiorize them, and thus could create a seemingly defensible rationale to naturalize slavery, domination and discrimination (Brown, 1993: 659560).

At first, the enterprise of colonization was demonstrated to be a kind of missionary practice which was dutifully carried out to enlighten and civilize the heathen peoples through Christianity (Fredrickson, 2002: 38). By imputing the black color of the negroid to the biblical curse of Ham or Canaan, the immoral aspects of exploitation and plundering could easily be condoned since they were seen as the natural outcome of the alleged inferiority of the black race (MacCann, 2001: xxviii-xxix). However, the hegemonic discourse of white superiority and black inferiority lacked a tenable scientific basis up to the mid-nineteenth century when Charles Darwin posited his groundbreaking theories. Though Darwin was in the first place concerned with the biological evolution of animal species and almost never dealt with the cultural or social implications of his theories, many others, such as Alfred Russel Wallace and Herbert Spencer, reasoned that Darwinist 
principles on biological evolution could be equally applied to human societies (Paul, 2003: 215). Social Darwinists held that in comparison with the Western civilization, other races had presumably evolved less far, as in Africa, or had developed into degeneracy, as in the East. Though the new 'scientific' findings were used as a justification to enact discriminating sociopolitical rules against all non-European races, it was blacks who became the easy butt of the social implications of Darwin's theories (Childs, 2000: 40-42).

Besides Europe, the same fixating mechanism of Otherization, inferiorization and subalternization was utilized in the United States where many of the sociopolitical elites of society, who were themselves slaveholders and landowners, had a vested interest in the perpetuation of the pattern of domination and subordination (Greenfield, 2001: 41). Resorting to the hierarchical rhetoric of the Calvinist thought (Robbins, 2007: 22) and later to Social Darwinism (Jones, 2010: 193), the mainstream American society, driven by sheer mercantile interest (Williams, 1944: 19-20), engendered an aura of sacrosanctity around the constructed concept of white supremacy and black servitude (Keim, 7-10: 2009). The centuries-long pattern of domination was so overbearing in the American society that remained mostly intact even after the emancipation. The consequence of this hegemonic discourse of inferiorization was a marginalized black deprived of his basic civil rights. In a society where the black subject "had no rights that the white man was bound to respect” (Judge Taney, as cited in Stewart, 2007: 13), Uncle Tomism was the safest strategy of survival that could be employed by the subalternized black.

Due to the unbearable weight of preponderant demeaning stereotypes and the discriminatory atmosphere of the pre-twentieth century America which denounced black pigmentation and sociocultural norms as deviant and base, most of the Negroes, divested of self-respect and self-confidence, rejected their African ancestral background and came to internalize whatever white dominators imposed on them; in other words, the American capitalist sociopolitical structure compelled blacks to internalize its negative stereotypes of their material conditions and their color of skin, which represented blacks as soul-less, poor, depraved, uncultured, irrational, and savage; a hegemonic pattern which finally eventuated in blacks' self-hatred and their efforts to live like the powerful bourgeois whites. Amidst this racial, sociopolitical and economic discrimination, blacks opted for the assimilation and reproduction of white America's norms in order to ameliorate their material conditions and achieve economic gain and sociocultural status; this integrationist agenda ultimately resulted in African Americans' cultural amnesia and collective loss of memory about the content and essence of their history and customs (Mocombe, 2009: 33-37). 
However, the dominant representational strategy of the late nineteenth century United States which depicted blacks as "an inferior breed ... situated at the very base of the evolutionary tree” (Digby Baltzell, as cited in Washington, 2001: 20) was soon to undergo a huge, drastic metamorphosis which was caused by a number of overlapping trends which will be briefly explained here. Many of the famed artists of the late nineteenth and early twentieth century, sick of the materialistic and artificial values of Western civilization, went for black forms of artistic expression in order to find a refuge from the uncompromising conventions of Victorian academia (Washington, 2001: 32; Staszak, 2004: 354). The outcome of the unprecedented fascination of avant-garde artists such as Gauguin, Picasso, Matisse, etc., with "l'art nègre" was the inception of the cult of modernist primitivism which undermined the over attenuated forms of Western art and brought the long-neglected black art and culture to the fore, not only in Europe but also in America (Rubin, 2006: 131). Alongside modernist primitivism, Boasian anthropology also played an influential role in helping blacks win their missing self-esteem. Intent on the disruption of the racist implications of Social Darwinism, Boas employed anthropology as a tool to scientifically prove that the notion of the natural inferiority of the black race is no more than a fallacious historical construct (Baker, 2004: 37-38). Early twentieth century was also the era of Africanism and Garvey's "Back to Africa” movement which encouraged African Americans, "orphaned" in the Diaspora, to discover their heroic lineage and reclaim their selfconfidence (Dawahare, 2003: 7). Besides all these factors, the mass exodus of more than one million black Americans form the agricultural rural South to the industrial urban North between 1916 and 1930, known as the Great Migration, undermined the old conceptions blacks held about themselves and urged them to reconceptualize their identity since it brought about multitudes of blacks into a cash economy for the first time and thus created new pockets of African American sociopolitical power (Alexander and Rucker, 2010: 787-788; Lentz-Smith, 2009: 34)

The last factor mentioned here, by no means the least, is the crucial event of World War I, which ushered African Americans into an age of redefinition. African Americans' contribution to the cause of war changed the way blacks thought about themselves and the nature of their citizenship in the United States. The confluence of blacks' participation in World War I and other groundbreaking occurrences gave rise to a new consciousness in the African American community out of which emerged a New Negro who, in the words of A. Philip Randolph, was "radical", "fearless" and "uncompromising” (as cited in Allen, 1991: 50). 


\section{African Americans and the Cause of War: A Quest for Recognition}

[A]s white southerners perfected a system of segregation and oppression and sought to export it beyond regional and national boundaries, many African Americans looked to use World War I to forestall white supremacy's ascent and to fulfill their quest for racial justice. For families and church groups, newspaper editors and organizations like the National Association for the Advancement of Colored People (NAACP), soldiers became emblems and agents in this struggle. (Lentz- Smith, 2009: 4)

The United States entered World War I in April 1917 and shortly afterwards, maybe out of the great exigency to fill the military ranks (Ciment, 2007: 128), or due to the fear of the endangerment of white women if black men stayed at home while white men were dispatched to war (Thomas, 2008: 47), or on account of a political agenda to avoid having a treacherous fifth column in the country during war time (Early, 2008: 12), the authorities asked African Americans to sacrifice for the country in the "War for Democracy". Nevertheless, resistance was great, especially in the South where whites had qualms about the possibility that a uniform and a military service would make blacks reluctant to acquiesce to their inferior sociopolitical status (Ciment, 2007: 128). This apprehension is best captured in the words of a general who stated: "In talking with southern members of Congress, I find a very natural repugnance to the idea [of the draft] due to their own local conditions. It is not that they disbelieve in more or less universal training on principle. But they do not like the idea of looking forward five or six years by which time their entire male Negro population will have been trained to arms" (as cited in Thomas, 2008: 46). Consequently, the war years witnessed a resurgence of hostility toward African Americans and a wave of violence was unleashed against them with almost 120 lynchings, largely committed in the South (Alexander and Rucker, 2010: 1110).

In a similar manner to that of Civil War, African Americans pinned their hopes upon the promise that their patriotic service in the cause of war would help them to win approval, recognition, and equality in the mainstream American society. Considering the Great War as "a wonderful opening of opportunities for the American Negro" (Kathryn Johnson, as cited in Lentz- Smith, 2009: 38) and holding that "the black man has nothing to lose and everything to gain" (James Bond, as cited in Lentz- Smith, 2009: 38), African Americans who favored black involvement in the war maneuvered on this supposition that they could earn the acclaim of the white society and subsequently citizenship rights through their heroic display of valiant qualities. 
As the nativist fervor was at its culmination at the time of World War I, there were blacks who claimed that they were "100-per-cent American, without alien sympathies and without hyphenate allegiance” (Emmett J. Scott, as cited in Early, 2008: 10). Henry Hugh Proctor, a black Atlanta pastor, for instance, declared his support for the United States' alleged endeavor for human liberty and reminded black Americans that "we are Americans by birth and breeding, service and sympathy" and advised them to allow "no words of disloyalty fall" from their lips (as cited in Lentz- Smith, 2009: 40). In a similar vein, the black elite, including many members of the NAACP (The National Association for the Advancement of Colored People), called for greater involvement of African Americans in the war effort. One of the most memorable statements regarding black participation belongs to W. E. B. DuBois, one of the co-founders of NAACP, who pragmatically and expediently contended that African Americans should fight "shoulder to shoulder with ... white fellow citizens and the allied nations that are fighting for democracy” (as cited in Early, 2008: 11). In his view, black Americans would either "fight or work" during the war; if they took part in the war, "they would learn the fighting game and cease to be so 'aisly lynched"”; and if they stayed in the country and worked, they would "learn the more lucrative trades and cease to be so easily robbed.” Either way, he assumed that the war would help blacks to subvert white supremacy and win recognition (as cited in Lentz- Smith, 2009: 40).

By the end of the war, more than 365,000 black Americans were enlisted and more than 200,000 of them were dispatched to Europe. Nonetheless, the majority of them were demoted to the lowest ranks or were transferred to Service of Supplies units and labor battalions, and just a few black combat regiments were formed. Paradoxically, it was this persistent discrimination that provided black soldiers with a great chance to prove their humanity and courage. The all-black unit of $369^{\text {th }}$ U.S. Infantry was being trained in Spartanburg, South Carolina. At the same time, France, in dire need of soldiers to fill their vacant ranks, asked the United States for more troops and the American military, trying to evade the protests and threats of violence against black training in South Carolina, sent the unit to France (Ciment, 2007: 128-129). The $369^{\text {th }}$ unit established an American World War I record for 191 days of incessant combat in the Argonne Forest where they warded off extensive German assaults on Chateau-Thierry and Belleau Wood (Alexander and Rucker, 2010: 1111-1112). Called the "Men of Bronze" by the French and the "Hellfighters" by the Germans, the $369^{\text {th }}$ spent more than six months on the front lines (more time than any other American unit in the war), had none of its soldiers taken prisoner, and lost no ground to the Germans. With 3500 soldiers killed in action, the $369^{\text {th }}$ received a collective Croix de Guerre citation and 171 officers and men were granted individual Croix de Guerres or Legions of Merit (Farrar, 2005: 353). 


\section{II.I. Welcomed with Lynch Mobs: African Americans' Unrewarded Service}

Who was the fool anyway, who thought of putting niggers into the same uniform with white men? (Faulkner, Sartoris, as cited in Wainwright, 2008: 40)

Notwithstanding their exemplary military service, African American soldiers were met with contempt by whites once they returned to America after the war. The post-war attitude of whites toward black veterans is best captured in the words of a New Orleans city official who reminded African American soldiers that "you are going to be treated exactly like you were before the war; this is a white man's country, and we expect to rule it” (as cited in Ciment, 2007: 129). Even though respected by the French and feared by the Germans, no U.S. Medals of Honor were granted to black troops at the time for their bravery; instead, the American army vigorously depreciated the performance of black combat units. After the war, several studies were carried out to prove that blacks were physically ineligible for combat duty because their brains were considered to be smaller than whites'. A rough consensus was formed in the army that black combat units should be kept to a minimum in the future wars and that most of black enlistees and draftees should be demoted to menial tasks. Under such circumstances, no advanced section, such as the Signal Corps or Air Corps, was to employ blacks; the Navy, which had previously used its black sailors only as messmen and stewards, decided to accept no new black soldiers, a decision which guaranteed an all-white Navy in the future; and the Marines continued to bar Negroes on the whole. Black American soldiers were not even allowed to attend the victory parades held in Paris and London after the war, and they were only celebrated with parades in African American communities (Farrar, 2005: 353).

When they returned to the United States, black veterans encountered a country engulfed in an unprecedented wave of racism. Right after the war, lynching considerably increased in the South and race riots ravaged the North. Racist white southerners, afraid of the looming threat of thousands of black men with ideas of social equality stemming from their overseas military service and armed battle experience, thought nothing of committing the most atrocious deeds in order to bolster white supremacy and black submission. In 1919, for instance, seventyseven blacks were lynched, ten of whom were veterans still in uniform. In the North, returning white soldiers understood that many of their jobs had been given during the war to Negro migrants from the South. The resulting tensions culminated in a number of race riots taking place from 1919 to 1921 in New York, Washington, D.C., Chicago, Omaha, Tulsa and many other cities (Farrar, 2005: 354; Carlisle, 2008: xvi). 


\section{II.II. Conception of a New Consciousness: Birth of a New Negro}

The war of 1914-1918 has created a new sentiment throughout the world. Once upon a time weaker peoples were afraid of expressing themselves, of giving vent to their feelings, but today no oppressed race or nation is afraid of speaking out in the cause of liberty. (Marcus Garvey, as cited in Dawahare, 2003: 3)

Although the heroic contributions of African American soldiers in the World War I were ignored by white America, it originated a drastic metamorphosis in the American Negro since it "sloughed off some of the emotional and intellectual accretions that swathed him round, and he stood partially for what he was" (Redding, 1966: 13). The war had shown the Negro that he had some power; as one white investment banker noted, the post-war Negro was not "as jolly, care-free, and good-natured as he once was ... His leaders - especially of the North through the Northern Negro press - are shaming him into a new attitude” (as cited in Jordan, 2001: 134). The migration of hundreds of thousands of Negroes from the sociopolitically oppressive rural South to the more thriving and less discriminatory urban North, the recent participation of more than 365,000 African Americans in the military operations, the active involvement of blacks at home to the cause of a war expected to make world safe for democracy, and the self-assertion of diverse ethnic minorities throughout Europe made many black Americans aware of the new opportunities of achieving freedom through activism (Jordan, 2001: 144).

If the stress during the war had been put on patriotism and collaboration in the war effort, assertive demands now eclipsed reaffirmations of loyalty and repudiations of radicalism. The post-World War I era witnessed the creation and empowerment of the "New Negro", marked by confidence, assertiveness and belligerence. This new consciousness resulted in a mounting optimism among the black sociopolitical and intellectual circles that armed self-defense and pugnacious assertiveness would decrease violence against Negroes and enhance their sociopolitical influence. Believing that a right to national citizenship was grounded in doing one's patriotic duty and fighting for the nation, African American activists of the day stated blacks' contribution to the war effort as a rationale to ask the white-dominated society to give them their rights; first, because they deserved them and second, because they were now strong enough to fight for them (Jordan, 2001: 134-8). Employing President Wilson's “War for Democracy” motto as an instrument in achieving black Americans' long-denied civil rights (Lentz- Smith, 2009: 34), black activists called for "that which we claim to have been fighting for, to establish a true and everlasting Democracy” (James P. Webb, as cited in Jordan, 2001: 146). They believed that the militant spirit demonstrated by African 
American soldiers in World War I wouldn't allow them to obediently embrace second-class citizenship in the United States (Allen, 1991: 49-50; Early, 2008: 10). As Chicago Defender noted:

We are loath to believe that the spirit which 'took no prisoners' will tamely and meekly submit to a program of lynching, burning and social ostracism as has obtained in the past. ... we shall look forward to a new tomorrow, not of subservience, not of meek and humble obeisance to any class, but with a determination to demand what is our due at all times and in all places. (as cited in Jordan, 2001: 146)

'America must be told' became the battle cry of the black civil rights activists after the war and they attempted to notify white America of the moral consequences of racism for the whole nation and to ask enlightened whites to align themselves with African Americans' quest for equality, democracy, and justice before the destructive explosion of the dreams deferred of the marginalized, but then bellicose and assuming blacks (Jordan, 2001: 135). The New Negro was born, "vibrant with a new psychology" and characterized by "self-respect and self-dependence" (Locke: 1-2); the New Negro expected to be respected.

\section{Conclusion}

The First World War was a watershed that gave many "the feeling of having lived in two eras, almost on two different planets" (Cowley, 1973: vii). In effect, World War I, with its heinous bloodshed, disrupted the prestige of Western civilization and its seemingly inviolable rhetoric of rationality and progress in the eyes of both whites and blacks; the white culture was no more deemed as the one unique regulator of cultural norms and conventions (Early, 2008: 13). After the war, there emerged a variety-seeking fad for making everything new and thus New Politics, New Sexuality, New Woman, and even New Negro surfaced in a short period of time (Allen, 1991: 48). In the turbulent atmosphere of post-World War I era, black soldiers, having experienced relative freedom in Europe, returned to Jim Crow United States; notwithstanding, this time blacks were not the same submissive Uncle Toms at beck and call of the white dominators (Hutchinson, 2007: 6).

The dominant spirit of post-World War I African American community was that of self-determination which gave rise to "a directness, forthrightness, and confrontational uprightness of men and women willing to demand rights, grab them by the throat if necessary" (Stewart, 2007: 15). All the major intellectual, social and political circles of post-war black America were all bound together by a new 
consciousness which prioritized self-assertion and self-definition against the hegemonic discourse of white supremacy (Hutchinson, 2007: 1).

Though one can claim that black participation in the war did not cause any major improvement in the sociopolitical status of African Americans in the United States, it is incontestable that it inspired a New Negro who dared to come out of his marginalized, obsequious mold and think about his identity in more sophisticated terms. Blacks' contribution to the cause of war politicized blacks and naturalized the up-to-then intimidating and taboo concepts of self-determination, collective identity-construction and separatism in black America (Early, 2008: 13). Uncle Tom was dead after the end of the Great War; the New Negro was then born.

\section{References and Notes}

1. Alexander, Leslie M., \& Rucker, Walter C., Eds. (2010). Encyclopedia of African American History, California: ABC-CLIO, LLC.

2. Allen, Ernest, Jr. (1991). "The New Negro Explorations in Identity and Social Consciousness, 1910-1922.” 1915: The Cultural Moment. Eds. Adele Heller and Lois Rudnick. New Brunswick: Rutgers University Press, pp. 48-68.

3. Baker, Lee D. (2004). "Franz Boas out of the Ivory Tower”, Anthropological Theory, Volume 4, Issue 1, pp. 29-51.

4. Brown, Richard Harvey (1993). "Cultural Representation and Ideological Domination”, Social Forces, Volume 71, Issue 3, pp. 657-676.

5. Carlisle, Rodney P., Ed. (2008). Day by Day: The Twenties, New York: Facts On File.

6. Childs, Peter (2000). Modernism, London: Routledge.

7. Ciment, James (2007). Atlas of African-American History, New York: Facts On File.

8. Cowley, Malcom (1973). A Second Flowering, London: Andre Deutsch.

9. Dawahare, Anthony (2003). Nationalism, Marxism, and African American Literature between the Wars, Jackson: University Press of Mississippi.

10. Early, Gerald (2008). "The New Negro Era and the Great African American Transformation”, American Studies, Volume 49, Issue 1, pp. 9-19.

11. Farrar, Hayward "Woody" (2005). "The Black Soldier in Two World Wars." A Companion to African American History. Ed. Alton Hornsby, Jr. MA: Blackwell Publishing, pp. 349-363.

12. Fredrickson, George M. (2002). Racism: A Short History, New Jersey: Princeton University Press.

13. Greenfield, Sidney M. (2001). "Nature/Nurture and the Anthropology of Franz Boas and Margaret Mead as an Agenda for Revolutionary Politics”, Horizontes Antropológicos, Volume 7, Issue 16, pp. 35-52.

14. Hutchinson, George (2007). Introduction. The Cambridge Companion to the Harlem Renaissance. Ed. George Hutchinson. Cambridge: Cambridge University Press, pp. 110 . 
15. Jones, Jeannette Eileen (2010). “Simians, Negroes, and the 'Missing Link': Evolutionary Discourses and Transatlantic Debates on 'The Negro Question'." Darwin in Atlantic Cultures: Evolutionary Visions of Race, Gender, and Sexuality. Eds. Jeannette Eileen Jones and Patrick B. Sharp. New York: Routledge, pp. 191-207.

16. Jordan, William G. (2001). Black Newspapers and America's War for Democracy, 1914-1920, Chapel Hill: The University of North Carolina Press.

17. Keim, Curtis A. (2009). Mistaking Africa: Curiosities and Inventions of the American Mind. $2^{\text {nd }}$ ed. Boulder: Westview Press.

18. Lentz-Smith, Adriane Danette (2009). Freedom Struggles: African Americans and World War I, Cambridge: Harvard University Press.

19. Locke, Alain. “The New Negro”. < http://freedownload.is/pdf/the-new-negro-19251alain-locke-5627071.html > (Accessed 6 September, 2012)

20. MacCann, Donnarae (2001). White Supremacy in Children's Literature, New York: Routledge.

21. Mocombe, Paul C. (2009). The Soul-less Souls of Black Folk, Lanham: University Press of America.

22. Paul, Diane B. (2003). "Darwin, Social Darwinism and Eugenics.” The Cambridge Companion to Darwin. Eds. Jonathan Hodge and Gregory Radick. Cambridge: Cambridge University Press, pp. 214-239.

23. Redding, Saunders (1966). "The Negro Writer and American Literature.” Anger and Beyond: The Negro Writer in the United States. Ed. Herbert Hill. New York: Harper \& Row, pp. 1-19.

24. Robbins, Sarah (2007). The Cambridge Introduction to Harriet Beecher Stowe, Cambridge: Cambridge University Press.

25. Rubin, William (2006). “Modernist Primitivism: An Introduction.” The Anthropology of Art: A Reader. Eds. Howard Morphy and Morgan Perkins. MA: Blackwell Publishing, pp. 129-146.

26. Staszak, Jean-François (2004). "Primitivism and the Other: History of Art and Cultural Geography”, GeoJournal, Volume 60, pp. 353-364.

27. Stewart, Jeffrey C. (2007). “The New Negro as citizen.” The Cambridge Companion to the Harlem Renaissance. Ed. George Hutchinson. Cambridge: Cambridge University Press, pp. 13-27.

28. Thomas, William H., Jr. (2008). Unsafe for Democracy: World War I and the U.S. Justice Department's Covert Campaign to Suppress Dissent, Wisconsin: The University of Wisconsin Press.

29. Wainwright, Michael (2008). Darwin and Faulkner's Novels: Evolution and Southern Fiction, New York: Palgrave Macmillan.

30. Washington, Robert E (2001). The Ideologies of African American Literature, Lanham: Rowman \& Littlefield Publishers.

31. Williams, Eric (1944). Capitalism \& Slavery, Chapel Hill: The University of North Carolina Press. 


\title{
Summary
}

\section{African Americans and Reconceptualization of Identity: Black Participation in World War I and the Rise of the New Negro Consciousness}

\author{
Farshid Nowrouzi Roshnavand \\ University of Tehran, Iran \\ Rajabali Askarzadeh Torghabeh \\ Ferdowsi University of Mashhad, Iran
}

Before the beginning of the twentieth century, the American Negro had undergone an allencompassing process of Otherization and inferiorization which represented blacks as inhuman, heathen and demonic. Under the tenacious hold of Calvinism, Capitalism and most notably Social Darwinism, blacks were forced to internalize the dominant negative stereotypes and thus over time came to view Uncle Tomism and assimilationism as the only possible survival strategies in the white-dominated United States. However, there emerged a paradigm shift in African Americans' conception of themselves and their status in the country when a number of factors went hand in hand in the early twentieth century to undermine the long-held assumption of white supremacy and black inferiority. One of these factors was African American participation in World War I. The up-to-then subalternized, obsequious American Negro experienced relative freedom in Europe during war time and came to appreciate and later implement concepts like collective political entity, cultural identity and social activism. This paper tries to analyze African Americans' contribution to the cause of World War I and the way it managed to usher blacks into an age of redefinition through politicizing them.

Keywords: World War I, African Americans, New Negro, Self-determination, Identity. 